\title{
FAKTOR MINAT DAN PERAN PERKEMBANGAN SUKUK TERHADAP PEMBANGUNAN
}

\author{
${ }^{1}$ Chandra Satria, ${ }^{2}$ Suandi \\ ${ }^{1}$ Ekonomi Syariah STEBIS IGM Palembang. Email: Chandras@stebisigm.ac.id \\ ${ }^{2}$ Universitas Sjakhyakirti Palembang. Email: suandi@unisti.ac.id
}

\begin{abstract}
In the period between 2010 and the end of 2018, sharia products, especially sukuk in the Indonesian capital market, have shown quite good development. Total funds under management of sharia mutual funds, or better known as the Net Asset Value (NAV), are recorded at Rp 34.5 trillion. This figure is up by $21.8 \%$ compared to 2017 . The NAV reflects $6.82 \%$ of the total conventional and sharia mutual fund NAV. While the number of Islamic mutual funds that have been circulating in the public, there were 224 mutual funds. This figure increased by $23.1 \%$ compared to 2017. The number also reflects $10.7 \%$ of the total conventional and sharia mutual funds that have been circulating in public (OJK data sources for 2017 and 2018). In that period, the issuance of sukuk was conducted 104 times by 22 issuers and / or public companies with a total sukuk issuance value of $R p 22$ trillion or equivalent to $10.5 \%$ of the total bond issuance value. The still low total sukuk issuance value compared to the total bond issuance value shows that there are other factors that influence Issuers / PP's interest in issuing sukuk in addition to regulatory factors related to Islamic capital markets which have had a positive influence on the development of Islamic capital markets, especially sukuk
\end{abstract}

Keywords: Sukuk, Bonds, Interests of Issuers

\begin{abstract}
Abstrak
Dalam jangka waktu antara tahun 2010 sampai dengan akhir tahun 2018, produk syariah khususnya sukuk di pasar modal Indonesia telah menunjukkan perkembangan yang cukup baik. Total dana kelolaan reksa dana syariah, atau lebih dikenal dengan terminologi Nilai Aktiva Bersih (NAB), tercatat sebesar Rp 34,5 triliun. Angka ini naik sebesar 21.8\% jika dibandingkan dengan tahun 2017. NAB tersebut mencerminkan $6.82 \%$ dari total NAB reksa dana konvensional dan syariah. Sementara jumlah reksa dana syariah yang telah beredar di publik, tercatat sebanyak 224 reksa dana. Angka ini meningkat 23.1\% jika dibandingkan dengan tahun 2017. Jumlah tersebut turut mencerminkan $10.7 \%$ dari jumlah reksa dana konvensional dan syariah yang telah beredar di public (sumber data OJK tahun 2017 dan 2018). Dalam periode tersebut juga untuk penerbitan sukuk telah dilakukan 104 kali yang dilakukan oleh 22 Emiten dan atau Perusahaan Publik dengan total nilai emisi sukuk sebesar Rp 22 triliun atau setara dengan 10,5\% terhadap total nilai emisi obligasi. Masih rendahnya total nilai emisi sukuk dibandingkan total nilai emisi obligasi tersebut menunjukkan bahwa terdapat faktor-faktor lain yang mempengaruhi minat Emiten/PP untuk menerbitkan sukuk selain faktor peraturan terkait pasar modal syariah yang telah memberikan pengaruh positif terhadap perkembangan pasar modal syariah terutama sukuk
\end{abstract}

Kata Kunci: Sukuk, Obligasi, Minat Emiten 
78 | Chandra Satria, Suandi, Faktor Minat dan Peran Sukuk Terhadap Pembangunan....

\section{DASAR PEMIKIRAN}

\section{Latar Belakang}

Salah satu sasaran pengembangan pasar modal Indonesia adalah mengembangkan pasar modal berbasis syariah melalui penyusunan kerangka hukum dan produk pasar modal berbasis syariah. Sampai dengan saat ini, dalam rangka pengembangan kerangka hukum di bidang pasar modal syariah, Bapepam dan LK telah menerbitkan 3 Peraturan yaitu Peraturan Nomor IX.A.13 tentang Penerbitan Efek Syariah, Peraturan Nomor IX.A.14 tentang Akad-akad yang Digunakan dalam Penerbitan Efek Syariah, dan Peraturan Nomor II.K.1 tentang Kriteria dan Penerbitan Daftar Efek Syariah. Sedangkan produk syariah yang telah diterbitkan di Indonesia baru ada 3 jenis, yaitu Saham Syariah, Sukuk, dan Reksa Dana Syariah. Dalam kurun waktu antara

Total dana Pengelolaan reksa dana syariah, atau lebih dikenal dengan terminologi Nilai Aktiva Bersih (NAB), tercatat sebesar Rp 34,5 triliun. Angka ini naik sebesar $21.8 \%$ jika dibandingkan dengan tahun 2017. NAB tersebut mencerminkan $6.82 \%$ dari total NAB reksa dana konvensional dan syariah. Sementara jumlah reksa dana syariah yang telah beredar di publik, tercatat sebanyak 224 reksa dana. Angka ini meningkat 23.1\% jika dibandingkan dengan tahun 2017. Jumlah tersebut turut mencerminkan $10.7 \%$ dari jumlah reksa dana konvensional dan syariah yang telah beredar di public (sumber data OJK tahun 2017 dan 2018).

Sepanjang tahun 2018, porsi asing di Surat Berharga Negara (SBN), baik SUN maupun sukuk (SBSN) turun menjadi 37,72\% dari Januari 2018 sebesar 41,29\%. Berdasarkan data Ditjen Pengelolaan Pembiayaan dan Risiko Kementerian Keuangan, porsi asing di SBN per 28 Desember 2018 mencapai Rp 893,36 triliun atau 37,72\% dari total oustanding SBN sebesar Rp 2.368,45 triliun. Jumlah tersebut bertambah Rp 23,59 triliun dibandingkan posisi awal Januari 2018. Porsi kepemilikan asing tersebut turun dibandingkan dengan posisi akhir Januari 2018 yakni 41,29\% atau sebesar Rp 869,77 triliun. Dari sisi nilai, jumlah kepemilikan asing naik, hanya saja dari sisi persentase berkurang karena jumlah outstanding SBN pada akhir Januari 2018 baru mencapai Rp2.106,74 triliun

Dalam periode tersebut juga untuk penerbitan sukuk telah dilakukan 104 kali yang dilakukan oleh 22 Emiten dan atau Perusahaan Publik dengan total nilai emisi sukuk 
Ekonomica Sharia: Jurnal Pemikiran dan Pengembangan Ekonomi Syariah Volume 6 Nomor 1 Edisi Agustus $2020 \mid 79$

sebesar Rp 22 triliun atau setara dengan 10,5\% terhadap total nilai emisi obligasi. Masih rendahnya total nilai emisi sukuk dibandingkan total nilai emisi obligasi tersebut menunjukkan bahwa terdapat faktor-faktor lain yang mempengaruhi minat Emiten/PP untuk menerbitkan sukuk selain faktor peraturan terkait pasar modal syariah yang telah memberikan pengaruh positif terhadap perkembangan pasar modal syariah terutama sukuk

Perkembangan jumlah penerbitan sukuk dari tahun 2010 sampai dengan 2018 secara umum mengikuti perkembangan jumlah penerbitan obligasi konvensional. Pasar Surat Berharga Syariah Negara (SBSN) atau sukuk negara terus bertumbuh dalam 10 tahun terakhir. Pemerintah pun meraih berbagai pencapaian sepanjang perjalanan penerbitan instrumen tersebut. Direktur Jenderal Pengelolaan Pembiayaan dan Risiko Kementerian Keuangan Lucky Alfirman memaparkan, sejak pertama kali diperkenalkan pada tahun 2008, instrumen sukuk negara terus berkembang. Tiap tahunnya, rata-rata pertumbuhan jumlah penerbitan sukuk negara mencapai 30\%. Total akumulasi penerbitan sukuk negara melalui lelang, book building, dan private placement hingga Oktober 2018 telah mencapai lebih dari Rp 950 triliun atau setara US\$ 63 miliar. Sedangkan outstanding sukuk negara per 25 Oktober 2018 telah mencapai Rp 657 triliun. Sementara itu, penerbitan sukuk negara berbasis ritel juga terus tumbuh. Nilai akumulasi penerbitan Sukuk Ritel seri SR001 hingga SR010 mencapai Rp 144,7 triliun dengan jumlah investor sebanyak 243.364 orang.

Indonesia menjadi penerbit sukuk global terbesar di dunia dengan total penerbitan senilai US\$ 16,15 miliar per September 2018. Kondisi ini membuat Indonesia jauh mengungguli Arab Saudi yang berada di posisi kedua dengan nilai penerbitan sukuk global sebesar US\$ 9 miliar. Indonesia menjadi negara pertama yang menerbitkan Sovereign Green Sukuk di dunia pada tahun 2018. "Ini merefleksikan dukungan dan kontribusi Indonesia dalam mengembangkan pasar keuangan syariah domestik maupun internasional," kata Lucky di Gedung Dhanapala, Jakarta, Kamis (1/11). Sukuk negara juga telah membiayai berbagai proyek infrastruktur yang tersebar di 34 provinsi sebesar Rp 62,4 triliun dalam kurun waktu 2013-2018

Berdasarkan uraian diatas, maka peneliti tertarik untuk menyusun penelitian ini dengan tema "Faktor Minat Dan Peran Perkembangan Sukuk Terhadap Pembangunan" 


\section{Rumusan Masalah}

Adapun rumusan masalah yang dikaji dalam penelitian ini adalah

a. Apakah faktor-faktor yang mempengaruhi penerbitan sukuk di pasar modal?

b. Apakah peran dari perkembangan sukuk di pasar modal ini terhadap pembangunan Indonesia?

\section{Tujuan Penelitian}

Adapun tujuan dalam penelitian artikel ini adalah: Mengetahui faktor-faktor yang mempengaruhi minat Emiten atau Perusahaan Publik menurut Emiten atau Perusahaan Publik dan berdasarkan pendapat dari Penjamin Emisi Efek serta peran perkembangan sukuk terhadap pembangunan suatu Negara.

\section{TINJAUAN PUSTAKA}

\section{Pengertian Sukuk}

Dalam Shari'a Standard No.17 tentang Investment Sukuk yang diterbitkan oleh Accounting and Auditing Organization for Islamic Financial Institutions (AAOIFI) mendefinisikan Sukuk sebagai berikut: "Investment Sukuk are certificates of equal value representing undivided share in ownership of tangible assets, usufructs and services, or (in the ownership of) the assets of particular projects or special investment activity, however, this is true after receipt of the value of the sukuk, the closing of subscription and the employment of funds received for the purpose for which the sukuk were issued". Dari definisi di atas dapat dipahami bahwa sukuk merupakan sertifikat bernilai sama yang mewakili bagian tak terpisahkan dalam kepemilikan suatu aset berwujud, manfaat atau jasa, atau kepemilikan dari aset suatu proyek atau aktivitas investasi tertentu, yang terjadi setelah adanya penerimaan dana sukuk, penutupan pemesanan dan dana yang diterima dimanfaatkan sesuai dengan tujuan penerbitan sukuk.

Adapun Dewan Syariah Nasional (DSN) Majelis Ulama Indonesia (MUI) belum menggunakan istilah sukuk dan masih menggunakan istilah obligasi syariah. Dalam fatwa No.: 32/DSN-MUI/IX/2002 tentang Obligasi Syariah DSN-MUI mendefinisikan obligasi syariah sebagai berikut: 
Ekonomica Sharia: Jurnal Pemikiran dan Pengembangan Ekonomi Syariah Volume 6 Nomor 1 Edisi Agustus $2020 \mid 81$

“... suatu surat berharga jangka panjang berdasarkan prinsip syariah yang dikeluarkan Emiten kepada pemegang Obligasi Syariah yang mewajibkan Emiten untuk membayar pendapatan kepada pemegang Obligasi Syariah berupa bagi hasil/margin/fee serta membayar kembali dana obligasi pada saat jatuh tempo". Bapepam dan LK dalam Peraturan Nomor IX.A.13 tahun 2009 mendefinisikan sukuk sebagai berikut: "Efek Syariah berupa sertifikat atau bukti kepemilikan yang bernilai sama dan mewakili bagian yang tidak tertentu (tidak terpisahkan atau tidak terbagi (syuyu'/undivided share)) atas: 1. Aset berwujud tertentu (a'yan maujudat); 2. Nilai manfaat atas aset berwujud (manafiul a'yan) tertentu baik yang sudah ada maupun yang akan ada; 3. Jasa (al khadamat) yang sudah ada maupun yang akan ada; 4. Aset proyek tertentu (maujudat masyru' mu'ayyan); dan/atau 5. Kegiatan investasi yang telah ditentukan (nasyath ististmarin khashah)".

\section{Karakteristik sukuk}

Keunggulan sukuk terletak pada strukturnya yang berdasarkan aset berwujud, yang berarti bahwa nilai dari sukuk akan selalu terkait dengan nilai dari aset yang mendasarinya Ciri khas lain sukuk adalah pemegang sukuk berhak atas bagian pendapatan yang dihasilkan dari aset sukuk di samping hak dari penjualan aset sukuk, dan dalam hal sertifikat tersebut mencerminkan suatu kewajiban kepada pemegangnya, maka sukuk tersebut tidak dapat diperjualbelikan pada pasar sekunder, sehingga akan menjadi instrumen jangka panjang yang dimiliki hingga jatuh tempo atau dijual pada nilai nominal

Agen-agen Penjualan Sukuk yaitu : 1 Citibank; 2 Bank ANZ Indonesia; 3 Bank BRISyariah; 4 Bank Central Asia; 5 Bank CIMB Niaga; 6 Bank Commonwealth; 7 Bank Danamon Indonesia; 8 Bank DBS Indonesia; 9 Bank Mandiri (Persero); 10 Bank Maybank Indonesia; 11 Bank Mega; 12 Bank Negara Indonesia (Persero); 13 Bank OCBC NISP; 14 Bank Pan Indonesia; 15 Bank Permata; 16 Bank Rakyat Indonesia (Persero); 17 Bank Syariah Mandiri; 18 Bank Tabungan Negara (Persero); 19 Trimegah Sekuritas Indonesia; 20 Standard Chartered Bank; 21 Bank HSBC : Sumber: (pengelolaan Data sekunder). 
82 | Chandra Satria, Suandi, Faktor Minat dan Peran Sukuk Terhadap Pembangunan....

\section{Pengertian Obligasi}

Pengertian obligasi adalah surat utang jangka menengah maupun jangka panjang yang dapat diperjualbelikan. Obligasi berisi janji dari pihak yang menerbitkan Efek untuk membayar imbalan berupa bunga (kupon) pada periode tertentu dan melunasi pokok utang pada akhir waktu yang telah ditentukan, kepada pihak pembeli obligasi tersebut. Obligasi merupakan salah satu investasi Efek berpendapatan tetap yang bertujuan untuk memberikan tingkat pertumbuhan nilai investasi yang relatif stabil dengan risiko yang relatif lebih stabil juga, dibandingkan dengan saham. (Sumber OJK $\mathrm{RI})$

\section{Jenis-jenis obligasi pada umumnya:}

1. Obligasi Pemerintah, yaitu obligasi dalam bentuk Surat Utang Negara yang diterbitkan oleh Pemerintah RI. Pemerintah menerbitkan obligasi dengan kupon tetap (seri FR- Fixed Rate), obligasi dengan kupon variable (seri VR -Variable Rate) dan obligasi dengan prinsip syariah/ Sukuk Negara.

2. Obligasi Korporasi, yaitu obligasi berupa surat utang yang diterbitkan oleh Korporasi Indonesia baik BUMN maupun korporasi lainnya. Sama seperti obligasi pemerintah, obligasi korporasi terbagi atas obligasi dengan kupon tetap, obligasi dengan kupon variabel dan obligasi dengan prinsip syariah. Ada Obligasi Korporasi yang telah diperingkat atau ada yang tidak diperingkat.

3. Obligasi Ritel, yang diterbitkan oleh Pemerintah yang dijual kepada individu atau perseorangan melalui agen penjual yang ditunjuk oleh Pemerintah. Biasanya ada beberapa jenis yaitu ORI atau Sukuk Ritel 
Tabel. 2 .

Perbedaan Sukuk, Obligasi dan Saham

\begin{tabular}{|l|l|l|l|}
\hline \multicolumn{1}{|c|}{ Deskripsi } & \multicolumn{1}{c|}{ Sukuk } & \multicolumn{1}{c|}{ Obligasi } & \multicolumn{1}{c|}{ Saham } \\
\hline Prinsip Dasar & $\begin{array}{l}\text { Bukan merupakan } \\
\text { surat utang, } \\
\text { melainkan } \\
\text { kepemilikan } \\
\text { bersama atas suatu } \\
\text { aset/proyek }\end{array}$ & $\begin{array}{l}\text { Surat pernyataan utang } \\
\text { dari Issuer }\end{array}$ & $\begin{array}{l}\text { Kepemilikan saham } \\
\text { dalam perusahaan }\end{array}$ \\
\hline Klaim & $\begin{array}{l}\text { Klaim kepemilikan } \\
\text { didasarkan pada } \\
\text { aset/proyek yang } \\
\text { spesifik }\end{array}$ & $\begin{array}{l}\text { Emiten menyatakan } \\
\text { sebagai pihak } \\
\text { peminjam }\end{array}$ & $\begin{array}{l}\text { Menyatakan } \\
\text { kepemilikan } \\
\text { terhadap } \\
\text { perusahaan }\end{array}$ \\
\hline $\begin{array}{l}\text { Penggunaan } \\
\text { Dana }\end{array}$ & $\begin{array}{l}\text { Harus digunakan } \\
\text { untuk kegiatan usaha } \\
\text { yang halal }\end{array}$ & $\begin{array}{l}\text { Dapat digunakan untuk } \\
\text { apa saja }\end{array}$ & $\begin{array}{l}\text { Dapat digunakan } \\
\text { untuk apa saja }\end{array}$ \\
\hline Jenis Penghasilan & $\begin{array}{l}\text { Imbalan, bagi hasil, } \\
\text { margin, capital gain }\end{array}$ & $\begin{array}{l}\text { Bunga/kupon, capital } \\
\text { gain }\end{array}$ & $\begin{array}{l}\text { Dividen / capital } \\
\text { gain }\end{array}$ \\
\hline Underlying Asset & Perlu & Tidak Perlu & Tidak Perlu \\
\hline $\begin{array}{l}\text { Syariah } \\
\text { Endorsement }\end{array}$ & Perlu & Tidak Perlu & Tidak Perlu \\
\hline
\end{tabular}

Sumber: Direktorat Kebijakan Pembiavaan

\section{Pengertian Emiten}

Emiten adalah Pihak yang melakukan Penawaran Umum, yaitu penawaran Efek yang dilakukan oleh Emiten untuk menjual Efek kepada masyarakat berdasarkan tata cara yang diatur dalam peraturan Undang-undang yang berlaku. Emiten dapat berbentuk orang perseorangan, perusahaan, usaha bersama, asosiasi, atau kelompok yang terorganisasi. Emiten dapat menawarkan Efek yang berupa surat pengakuan utang, surat berharga komersial, saham, obligasi, tanda bukti utang, Unit Penyertaan kontrak investasi kolektif, kontrak berjangka atas Efek, dan setiap derivatif dari Efek. Jenis Efek yang lain adalah Sukuk, yang merupakan Efek Syariah, yakni akad dan cara penerbitannya sesuai dengan Prinsip Syariah di Pasar Modal. Pada umumnya, Emiten melakukan penawaran Efek melalui Pasar Modal untuk saham, obligasi, dan sukuk.

\section{Pengertian Perusahaan Publik}

Perusahaan Publik adalah Perseroan Terbatas seperti yang dimaksud dalam Pasal 1 angka 1 Ketentuan Umum Undang-undang Nomor 40 Tahun 2007 tentang Perseroan 
Terbatas. Sahamnya telah dimiliki sekurang-kurangnya oleh 300 (tiga ratus) pemegang saham dan memiliki modal disetor sekurang-kurangnya Rp 3.000.000.000 (tiga miliar rupiah) atau suatu jumlah pemegang saham dan modal disetor yang ditetapkan dengan Peraturan Pemerintah.

Emiten wajib menyampaikan Pernyataan Pendaftaran untuk melakukan Penawaran Umum dan Perusahaan Publik wajib menyampaikan Pernyataan Pendaftaran sebagai Perusahaan Publik. Atas Pernyataan Pendaftaran tersebut, Otoritas Jasa Keuangan (dahulu Bapepam-LK) memberikan pernyataan efektif yang menunjukkan kelengkapan atau dipenuhinya seluruh prosedur dan persyaratan atas Pernyataan Pendaftaran yang diwajibkan dalam peraturan perundangan yang berlaku. Pernyataan efektif tersebut bukan sebagai izin untuk melakukan Penawaran Umum dan juga bukan berarti bahwa Otoritas Jasa Keuangan menyatakan informasi yang diungkapkan Emiten atau Perusahaan Publik tersebut adalah benar atau cukup.

Profil perusahaan Emiten dan Perusahaan Publik Industri Sektor Riil terbagi dalam 8 (delapan) sektor industri dari 3 (tiga) bagian pemantauan Emiten dan Perusahaan Publik di lingkungan Direktorat Penilaian Keuangan Perusahaan Sektor Riil: a. Bagian Pemantauan Perusahaan Aneka Industri: 1) Sektor Perusahaan Tekstil, Garmen, dan Alas Kaki; 2) Sektor Perusahaan Barang Konsumsi; dan 3) Sektor Perusahaan Aneka Industri Lainnya. b. Bagian Pemantauan Perusahaan Industri Dasar Logam dan Kimia: 1) Sektor Perusahaan Industri Dasar; 2) Sektor Perusahaan Industri Logam; dan 3) Sektor Perusahaan Industri Kimia. c. Bagian Pemantauan Perusahaan Pertambangan dan Agrobisnis: 1) Sektor Perusahaan Pertambangan dan Kehutanan; dan 2) Sektor Perusahaan Agrobisnis (sumber OJK RI)

\section{PENELTIAN TERDAHULU}

Studi yang dilakukan oleh Graham dan Harvey (2001) menunjukkan bahwa terkait dengan pendanaan (fund raising), perusahaan mempertimbangkan financial flexibility dan credit rating dalam penerbitan obligasi, dan EPS dilution and the recent stock price appreciation dalam penerbitan saham Menurut Graham dan Harvey (2001) perusahaan akan menerbitkan surat utang jangka pendek apabila mereka berharap credit rating-nya 
Ekonomica Sharia: Jurnal Pemikiran dan Pengembangan Ekonomi Syariah Volume 6 Nomor 1 Edisi Agustus $2020 \mid 85$

membaik. Pada umumnya, rating menjadi hal yang penting dalam keputusan penerbitan surat utang. Surat utang jangka pendek tidak digunakan untuk menentukan perbaikan rating. Berkenaan dengan interest rate, penerbitan surat utang dilakukan pada saat tingkat suku bunga rendah. Selanjutnya, kesesuaian jangka waktu surat utang merupakan faktor yang digunakan untuk memilih surat utang jangka pendek dan jangka panjang

Bancel \& Mitto (2003) menunjukkan bahwa financial flexibility dan earning per share dilution merupakan faktor yang paling penting bagi manajer di Eropa untuk membuat keputusan mengenai capital structure. Faktor lain yang dianggap berpengaruh dalam pendanaan adalah pertimbangan hedging dan window opportunity, dan hasil dari interaksi yang komplek dari banyak fitur institusi dan praktik bisnis yang tidak dapat ditangkap secara penuh oleh perbedaan dalam sistem hukum.

Nagano (2009) yang secara empiris menginvestigasi perusahaan-perusahaan yang menggunakan pendanaan syariah di Malaysia dan negara Timur Tengah. Analisis perbandingan dari pengguna pendanaan syariah dan non syariah menghasilkan 3 (tiga) implikasi utama yaitu:

1. Perusahaan penerbit sukuk lebih memilih penerbitan sukuk sebelum pinjaman bank dan alat pendanaan lainnya.

2. Penerbitan sukuk tidak berkaitan dengan dana-dana internal (information cost) perusahan sementara pinjaman bank secara signifikan dipengaruhi oleh magnitude dana-dana internal perusahaan.

3. Penerbitan sukuk menyumbang kenaikan nilai pengembalian saham perusahaan dan total faktor produktivitas.

Bapepam dan LK telah melakukan studi juga tentang Investasi Syariah di Pasar Modal Indonesia (2004). Dalam studi tersebut telah teridentifikasi faktor-faktor yang secara umum dianggap sebagai kendala dan atau hambatan dalam pengembangan investasi syariah di Pasar Modal Indonesia diantaranya adalah: tingkat pengetahuan dan pemahaman tentang pasar modal syariah, ketersediaan informasi tentang pasar modal syariah, minat pemodal atas Efek Syariah, kerangka peraturan tentang penerbitan Efek Syariah, pola pengawasan (dari sisi syariah) oleh lembaga terkait, pra-proses (persiapan) 
86 | Chandra Satria, Suandi, Faktor Minat dan Peran Sukuk Terhadap Pembangunan....

penerbitan Efek Syariah, dan kelembagaan atau Institusi yang mengatur dan mengawasi kegiatan pasar modal syariah di Indonesia.

Angrum Pratiwi, Fakultas Ekonomi dan Bisnis Islam Samarinda angrum89@gmail.com Jurnal AL-TIJARY, Vol. 02, No. 02, Juni 2017 : Sukuk adalah sebuah representasi proporsional dari kepemilikan suatu aset untuk periode waktu tertentu dengan risiko dan pengembalian yang terkait dengan arus kas melalui aset dasar di tangan investor. Penelitian ini menjelaskan gambaran umum tentang peran sukuk dalam infrastruktur pembiayaan di Indonesia. Sukuk memainkan peran penting dalam infrastruktur pembangunan di Indonesia. Alokasi anggaran infrastruktur Indonesia secara bertahap meningkat. Sejumlah proyek tercantum dalam Anggaran Pendapatan dan Belanja Negara (APBN) dipilih secara khusus dibiayai oleh sukuk. Sejak penerbitan pembiayaan proyek sukuk telah berlipat dua sampai tahun ini. Ini menjadi perhatian penting bagi pemerintah itu sukuk ternyata menjadi instrumen keuangan penting dalam infrastruktur Indonesia pengembangan

\section{PEMBAHASAN}

\section{Faktor Yang mempengaruhi Penerbitan Sukuk Bagi Emiten/PP Sukuk.}

Bagi Emiten/PP sukuk yang telah menerbitkan sukuk, faktor eksternal merupakan faktor yang paling mempengaruhi Emiten dalam menerbitkan sukuk diikuti dengan faktor peraturan dan terakhir faktor internal Emiten.

1. Faktor Eksternal

Ditinjau dari faktor eksternal terdapat tiga faktor yang memberikan pengaruh besar bagi Emiten/PP sukuk untuk menerbitkan sukuk yaitu adanya kelebihan likuiditas pasar, dan cost of fund. Faktor kelebihan likuiditas pasar ini secara konsisten dianggap paling penting bagi Emiten/PP di sektor property dan real estate serta sektor perdagangan, jasa dan investasi, namun Emiten/PP yang bergerak di sektor infrastruktur, utilitas dan transportasi mereka beranggapan faktor cost of fund merupakan faktor yang paling penting. Nilai rata rata cost of fund untuk Emiten/PP infrastruktur, utilitas dan transportasi adalah 4,75 lebih tinggi dibanding nilai ratarata cost of fund untuk seluruh Emiten/PP yang hanya mencapai 4,29. Ketiga faktor 
Ekonomica Sharia: Jurnal Pemikiran dan Pengembangan Ekonomi Syariah Volume 6 Nomor 1 Edisi Agustus $2020 \mid 87$

tersebut, ternyata konsisten sebagai faktor yang mempengaruhi minat Emiten/PP dalam menerbitkan sukuk jika dilihat dari sisi total aset dan presentase saham publik, persentase kepemilikan asing dan Debt to Equity Ratio. Sementara itu ada tiga faktor eksternal yang menurut pendapat Emiten/PP bukan menjadi prioritas utama dalam pengambilan keputusan Emiten/PP untuk menerbitkan sukuk yaitu faktor variasi akad dan struktur sukuk yang ada di Indonesia, biaya jasa konsultasi kesesuaian syariah dan keterbatasan sumber lain dalam pendanaan perusahaan di luar sukuk

2. Faktor Peraturan

Terdapat tiga faktor yang sangat berpengaruh bagi Emiten/PP sukuk dalam menerbitkan sukuk dipasar modal yaitu faktor adanya ketentuan bahwa aset/kegiatan usaha yang mendasari penerbitan sukuk tidak bertentangan dengan prinsip syariah, faktor perlakuan perpajakan atas sukuk dan faktor kebijakan perusahaan dalam pendanaan (financing). Sementara itu ada tiga faktor eksternal yang menurut pendapat Emiten/PP sukuk bukan menjadi prioritas utama dalam pengambilan keputusan Emiten/PP untuk menerbitkan sukuk yaitu faktor ketentuan penyampaian hasil pemeringkatan sukuk setiap tahun, penggunaan dana hasil penerbitan sukuk harus sesuai dengan karakteristik akad syariah dan faktor keterbukaan informasi yang dipersyaratkan terkait dengan penerbitan sukuk.

3. Faktor Internal

Faktor yang sangat berpengaruh bagi Emiten/PP sukuk dalam menerbitkan sukuk dipasar modal yaitu faktor penerbitan sukuk dilakukan ketika industri keuangan syariah berkembang pesat. Hal ini konsisten bagi seluruh Emiten/PP baik berdasarkan karakteristik sektor industri, total aset, presentase saham publik, presentase kepemilikan asing dan debt to equity ratio. Sementara itu faktor penerbitan sukuk dilakukan ketika saham perusahaan di pasar undervalue, penerbitan sukuk dilakukan ketika banyak perusahaan menerbitkan sukuk, perusahaan memiliki direksi atau pejabat satu level di bawah Direksi yang memahami prinsip syariah merupakan faktor yang paling tidak berpengaruh bagi Emiten/PP untuk menerbitkan sukuk. 
88 | Chandra Satria, Suandi, Faktor Minat dan Peran Sukuk Terhadap Pembangunan....

\section{a. Faktor Yang mempengaruhi Penerbitan Sukuk Bagi Emiten/PP Non Sukuk}

Secara umum dari ketiga faktor utama yaitu faktor internal dan eksternal perusahaan serta faktor peraturan, faktor yang paling berpengaruh bagi responden Emiten/PP non sukuk sebagai pertimbangan untuk menerbitkan sukuk adalah faktor peraturan, kemudian diikuti faktor eksternal perusahaan dan faktor internal. Berikut diuraikan masing-masing dari faktor-faktor utama yang mempengaruhi Emiten/PP non sukuk dalam menerbitkan sukuk, yaitu:

1. Faktor Peraturan

Faktor peraturan yang paling berpengaruh menurut responden adalah keterbukaan informasi yang disyaratkan terkait dengan penerbitan sukuk; sumber pendapatan yang menjadi dasar bagi hasil, margin atau fee bagi pemegang sukuk; dan adanya ketentuan bahwa aset/kegiatan usaha yang mendasari penerbitan sukuk tidak bertentangan dengan prinsip syariah.

2. Faktor Eksternal

Faktor eksternal yang paling berpengaruh menurut responden adalah perlakuan perpajakan atas sukuk, ketersediaan profesi penunjang pasar modal yang kompeten di bidang pasar modal syariah, tingkat bunga risk free rate, ketersediaan informasi mengenai pasar modal syariah dan sosialisasi kepada pelaku pasar mengenai pasar modal syariah

3. Faktor Internal

Faktor internal yang paling berpengaruh menurut responden adalah faktor penerbitan sukuk dilakukan ketika industri keuangan syariah berkembang pesat, faktor ketersediaan SDM (Direksi dan/atau pejabat satu level dibawah direksi) yang memahami tentang hal-hal yang bertentangan dengan prinsip syariah serta faktor penerbitan sukuk merupakan subsitusi (pengganti) dari penerbitan obligasi konvensional.

\section{b. Faktor yang mempengaruhi penerbitan sukuk bagi penjamin emisi efek}

Secara umum dari ketiga faktor utama, faktor yang paling berpengaruh bagi Emiten/PP untuk menerbitkan sukuk menurut pendapat responden PEE adalah faktor eksternal, kemudian diikuti faktor peraturan dan faktor internal 
1. Faktor Eksternal

Faktor eksternal yang paling berpengaruh menurut responden adalah potensi pasar dalam menyerap sukuk, tersediannya profesi dan lembaga penunjang pasar modal yang mengerti prinsip syariah dan faktor perlakuan perpajakan atas sukuk

2. Faktor Berkaitan dengan Peraturan

Kejelasan Peraturan Bapepam dan LK yang mengatur dengan penerbitan sukuk dan Keterbukaan informasi yang dipersyaratkan terkait dengan penerbitan sukuk merupakan faktor utama yang mempengaruhi minat Emiten/PP dalam menerbitkan sukuk menurut pendapat PEE, hal ini dinyatakan oleh semua PEE yang menjadi responden. Sementara itu, bagi PEE yang memiliki total aset Rp 1 triliun -5 triliun dan PEE yang pernah menerbitkan obligasi di atas 20 obligasi, faktor keterbukaan informasi yang dipersyaratkan terkait dengan penerbitan Sukuk bukan merupakan faktor yang berpengaruh bagi Emiten/PP untuk menerbitkan sukuk menurut pendapat PEE

3. Faktor Internal

Faktor internal yang dianggap sangat mempengaruhi minat Emiten/PP untuk menerbitkan sukuk berdasarkan pendapat PEE yang pernah menjadi penjamin emisi sukuk dan atau obligasi adalah ketersediaan SDM (Direksi dan/atau pejabat satu level di bawah direksi) yang memahami tentang hal-hal yang bertentangan dengan prinsip.

\section{c. Faktor Tambahan yang Mempengaruhi Penerbitan Sukuk Bagi Emiten/PP}

2 faktor tambahan yaitu faktor prioritas pendanaan dan faktor biaya.

1. Faktor biaya

Dalam rangka mengetahui tingkat kemahalan biaya penerbitan sukuk dibandingkan dengan biaya penerbitan obligasi, Tim Studi menanyakan hal ini kepada responden Emiten/PP sukuk. Bentuk pertanyaan yang diberikan adalah apakah faktor-faktor biaya dalam rangka penerbitan sukuk lebih mahal dibandingkan dengan biaya penerbitan obligasi. Para responden diberikan pilihan jawaban "ya" atau "tidak". Hal menunjukkan bahwa dari 16 Emiten/PP sukuk yang menjawab pertanyaan ini, sebagian besar Emiten/PP sukuk menjawab "tidak". Hal ini berarti bahwa bagi 
90 | Chandra Satria, Suandi, Faktor Minat dan Peran Sukuk Terhadap Pembangunan....

Emiten/PP yang telah menerbitkan sukuk, faktor biaya penerbitan sukuk tidak lebih mahal dari biaya penerbitan obligasi.

2. Faktor prioritas Pendanaan

Dalam rangka mengetahui kebutuhan pendanaan eksternal dari pasar modal bagi Emiten/PP non sukuk, Tim Studi menanyakan hal ini kepada responden Emiten/PP non sukuk. Bentuk pertanyaan yang diberikan adalah apakah dalam satu tahun kedepan perusahaan saudara membutuhkan pendanaan eksternal dari pasar modal. Para responden diberikan pilihan jawaban "ya" atau "tidak". Dalam hal responden menjawab "ya", Tim Studi kemudian menanyakan mengenai prioritas jenis pendanaan dari pasar modal yang dipilih.

3. Berdasarkan kuesioner yang dijawab oleh responden Emiten/PP non sukuk, sebanyak 27 Emiten/PP non sukuk atau 30\% dari jumlah responden Emiten/PP non sukuk menyatakan bahwa dalam satu tahun mendatang perusahaan membutuhkan pendanaan eksternal melalui pasar modal dan 59 Emiten/PP non

\section{Peran perkembangan sukuk di pasar modal terhadap pembangunan Indonesia.}

Berdasarkan data Bursa Efek Indonesia per Desember 2018, nilai outstanding sukuk negara adalah $\mathrm{Rp} 405,4$ triliun atau 95\% dari total outstanding sukuk. Nilai outstanding total sukuk adalah sebesar Rp426,8 triliun atau sebesar $15 \%$ dari total efek pendapatan tetap yang diterbitkan di Indonesia. Sementara itu, dari sisi sukuk korporasi, outstanding value sukuk korporasi syariah berkontribusi sebesar 5\% dari total outstanding value dengan jumlah sukuk sebanyak $15 \%$ dari total sukuk keseluruhan. outstanding value sukuk negara memiliki porsi $17 \%$ dari total outstanding value dengan jumlah sukuk sebanyak $37 \%$ dari total sukuk keseluruhan. Adapun, selama 5 tahun terakhir oustanding sukuk negara meningkat $8 \%$ menjadi Rp661,3 triliun atau sebanyak 18\% dari jumlah total SBN. Kadiv. Pasar Modal Syariah BEI Irwan Abdalloh perkembangan sukuk Dalam tempo 5 tahun terakhir, sudah tumbuh $8 \%$ nilai oustanding-nya

Total dana kelolaan reksa dana syariah, atau lebih dikenal dengan terminologi Nilai Aktiva Bersih (NAB), tercatat sebesar Rp 34,5 triliun. Angka ini naik sebesar $21.8 \%$ 
Ekonomica Sharia: Jurnal Pemikiran dan Pengembangan Ekonomi Syariah Volume 6 Nomor 1 Edisi Agustus 2020 |91

jika dibandingkan dengan tahun 2017. NAB tersebut mencerminkan $6.82 \%$ dari total NAB reksa dana konvensional dan syariah. Sementara jumlah reksa dana syariah yang telah beredar di publik, tercatat sebanyak 224 reksa dana. Angka ini meningkat $23.1 \%$ jika dibandingkan dengan tahun 2017. Jumlah tersebut turut mencerminkan 10.7\% dari jumlah reksa dana konvensional dan syariah yang telah beredar di public (sumber data OJK tahun 2017 dan 2018).

Sepanjang tahun 2018, porsi asing di Surat Berharga Negara (SBN), baik SUN maupun sukuk (SBSN) turun menjadi 37,72\% dari Januari 2018 sebesar 41,29\%. Berdasarkan data Ditjen Pengelolaan Pembiayaan dan Risiko Kementerian Keuangan, porsi asing di SBN per 28 Desember 2018 mencapai Rp 893,36 triliun atau 37,72\% dari total oustanding SBN sebesar Rp 2.368,45 triliun. Jumlah tersebut bertambah Rp 23,59 triliun dibandingkan posisi awal Januari 2018. Porsi kepemilikan asing tersebut turun dibandingkan dengan posisi akhir Januari 2018 yakni 41,29\% atau sebesar Rp 869,77 triliun. Dari sisi nilai, jumlah kepemilikan asing naik, hanya saja dari sisi persentase berkurang karena jumlah outstanding SBN pada akhir Januari 2018 baru mencapai Rp2.106,74 triliun, Dalam periode tersebut juga untuk penerbitan sukuk telah dilakukan 104 kali yang dilakukan oleh 22 Emiten dan atau Perusahaan Publik dengan total nilai emisi sukuk sebesar Rp 22 triliun atau setara dengan 10,5\% terhadap total nilai emisi obligasi.

Berikut beberapa manfaat dari perkembangan sukuk di Indonesia

1. Sukuk Negara merupakan sumber pembiayaan APBN

Saat ini, outstanding Sukuk Negara sekitar 18 persen dari total outstanding Surat Berharga Negara (SBN), Dalam tiga tahun anggaran terakhir, penerbitan Sukuk Negara berada di kisaran 27-30 persen dari total penerbitan SBN dalam rangka pembiayaan APBN. Sejalan dengan karakteristik keuangan syariah yang mengharuskan keterkaitan langsung antara instrumen keuangan dan sektor riil, pembiayaan APBN melalui Sukuk Negara ini mendukung pembiayaan APBN yang produktif. Sebagian besar penerbitan Sukuk Negara dalam bentuk Project-based Sukuk (PBS), di mana dasar penerbitan Sukuk Negara ini adalah proyek-proyek infrastruktur pemerintah (Sumber: republika.co.id: Suminto, Staf Ahli Menteri Keuangan Bidang Pengeluaran Negara/Anggota Pleno DSN MUI). 


\section{2 | Chandra Satria, Suandi, Faktor Minat dan Peran Sukuk Terhadap Pembangunan....}

2. Sukuk Negara menjadi instrumen penting dalam inklusi keuangan.

Melalui berbagai varian Sukuk Negara Ritel, Sukuk Negara menjadi instrumen investasi berbasis syariah penting bagi masyarakat. Melalui 10 seri Sukuk Ritel (Sukri) dan satu seri Sukuk Tabungan (ST), telah diterbitkan sekitar Rp 147 triliun Sukuk Negara Ritel yang diperuntukkan bagi investor perorangan, dan sudah dibeli sekitar 255 ribu orang. Sukuk Negara Ritel efektif dalam mentransformasi masyarakat, dari saving oriented society menjadi investment oriented society. Melalui Sukuk Negara Ritel berbasis syariah, yang diterbitkan pemerintah dan memiliki imbalan kompetitif, masyarakat memiliki insentif untuk berinvestasi pada produk pasar modal sekaligus belajar berbagai instrumen investasi di pasar modal.

3. Sukuk Negara menjadi instrumen pendorong perkembangan industri keuangan syariah di Tanah Air, baik perbankan syariah, IKNB syariah, maupun pasar modal syariah.

Sukuk Negara merupakan instrumen investasi dan pengelolaan likuiditas yang penting bagi industri keuangan syariah. Sukuk Negara juga menjadi acuan bagi korporasi dalam menerbitkan sukuk korporasi. Melalui sinergi antarinstrumen dan industri, industri keuangan syariah berkembang cukup baik. Merujuk data OJK, per 31 Agustus 2018, total aset perbankan syariah yang terdiri atas 13 bank umum syariah, 21 unit usaha syariah, dan 168 Bank Pembiayaan Rakyat Syariah mencapai Rp 445,24 triliun atau 5,72 persen dari total aset perbankan nasional. Total aset IKNB Syariah (asuransi, pembiayaan, penjaminan syariah) Rp 99,96 triliun atau 4,36 persen dari total aset IKNB nasional. Total dana kelolaan reksa dana syariah Rp 31,13 triliun atau 6,31 persen dari total dana kelolaan reksa dana nasional. (Sumber, Global Islamic Finance Report 2018)

4. Sukuk Negara mendukung stabilitas pasar keuangan.

Sekitar 95 persen Sukuk Negara dalam denominasi rupiah dipegang investor domestik, baik investor institusi maupun perorangan, Perilaku investor syariah cenderung prudent dan tidak spekulatif juga sangat mendukung. Stabilitas pasar Sukuk Negara ini, antara lain, dapat diamati pada volatilitas yield Sukuk Negara yang lebih rendah dibandingkan pasar obligasi.

5. Sukuk Negara menjadi katalis keuangan syariah di tataran global 
Ekonomica Sharia: Jurnal Pemikiran dan Pengembangan Ekonomi Syariah Volume 6 Nomor 1 Edisi Agustus 2020 | 93

Melalui penerbitan Sukuk Negara Global dalam denominasi dolar AS secara reguler, Sukuk Negara telah menjadi instrumen investasi dan pengelolaan likuiditas yang penting bagi industri keuangan syariah global. Sukuk Negara Global yang diterbitkan Indonesia mencapai Outstanding sukuk korporasi sebesar Rp 17,34 triliun atau 4,15 persen dari total outstanding obligasi korporasi. Sedangkan saham syariah dari 395 emiten, mencapai Rp 3.555 triliun atau 52,41 persen dari total kapitalisasi pasar saham Ini didukung beberapa faktor, yakni inovasi instrumen yang menjadi global trend setter, baik terkait struktur syariah maupun tema

\section{SIMPULAN}

Berdasarkan analisis dan pembahasan yang telah diuraikan dalam pembahasan diatas dapat disimpulkan beberapa hal sebagai berikut:

1. Berdasarkan klasifikasi bidang usaha perusahaan yang ada di Bursa Efek Indonesia, dapat disimpulkan bahwa perusahaan yang mempunyai kegiatan usaha di bidang infrastruktur, utilitas dan transportasi merupakan perusahaan yang paling sering menerbitkan sukuk. Untuk perusahaan di bidang property dan real estate; dan keuangan merupakan perusahaan yang cukup sering menerbitkan sukuk di pasar modal Indonesia, sedangkan perusahaan di bidang industri dasar dan kimia; industri barang konsumsi; dan pertambangan merupakan perusahaan yang jarang menerbitkan sukuk.

2. Secara umum faktor-faktor yang mempengaruhi minat Emiten/PP untuk menerbitkan sukuk tersebut dikelompokan menjadi 3 faktor utama yaitu faktor internal, faktor eksternal, dan faktor peraturan. Dari ketiga faktor utama tersebut, faktor yang paling berpengaruh dalam penerbitan sukuk adalah faktor eksternal, kemudian diikuti faktor peraturan dan faktor internal.

3. Bagi Emiten/PP yang pernah menerbitkan sukuk, faktor yang paling berpengaruh adalah faktor eksternal, sedangkan faktor yang paling tidak berpengaruh adalah faktor internal. Dari faktor eksternal tersebut, hal yang paling berpengaruh adalah kelebihan likuiditas di pasar. Dalam hal tidak dilakukan pengelompokan ke dalam 
94 | Chandra Satria, Suandi, Faktor Minat dan Peran Sukuk Terhadap Pembangunan....

3 faktor utama di atas, kelebihan likuiditas di pasar tersebut juga menjadi faktor yang sangat berpengaruh dalam penerbitan sukuk.

4. Bagi Emiten/PP yang belum pernah menerbitkan sukuk, faktor yang paling berpengaruh adalah faktor peraturan sedangkan faktor yang paling tidak berpengaruh adalah faktor internal. Dari faktor peraturan tersebut, hal yang paling berpengaruh adalah keterbukaan informasi yang dipersyaratkan terkait dengan penerbitan sukuk. Namun demikian, dalam hal tidak dilakukan pengelompokkan ke dalam 3 faktor utama di atas, perlakuan perpajakan atas sukuk merupakan hal yang memberikan pengaruh terbesar dalam penerbitan sukuk.

5. Menurut pendapat Penjamin Emisi Efek (PEE) yang pernah menjadi Penjamin Emisi Sukuk dan atau Obligasi, faktor yang paling mempengaruhi minat Emiten/PP untuk menerbitkan sukuk adalah faktor eksternal sedangkan faktor yang paling tidak berpengaruh adalah faktor internal. Dari faktor eksternal tersebut, ada dua hal yang paling berpengaruh yaitu potensi pasar dalam menyerap sukuk dan ketersediaan profesi dan lembaga penunjang yang mengerti prinsip syariah. Dalam hal tidak dilakukan pengelompokan ke dalam 3 faktor utama di atas, kedua hal tersebut juga menjadi faktor yang sangat berpengaruh dalam penerbitan sukuk.

6. Di samping 3 faktor utama tersebut di atas, terdapat 2 faktor tambahan yaitu faktor biaya dan faktor prioritas pendanaan. Bagi Emiten/PP yang sudah menerbitkan sukuk menyatakan bahwa biaya penerbitan sukuk tidak lebih mahal dari biaya penerbitan obligasi. Sementara itu, bagi Emiten/PP yang belum pernah menerbitkan sukuk dan merencanakan pendanaan eksternal melalui pasar modal menyatakan bahwa penerbitan sukuk bukan merupakan prioritas pertama.

\section{SARAN}

Berdasarkan pembahasan dan simpulan yang telah diuraikan maka direkomendasikan beberapa hal sebagai berikut:

1. Perlunya dilakukan sosialisasi yang terfokus kepada potential investor baik individu maupun intitusi seperti Reksa Dana, Asuransi, Dana Pensiun dan Bank 
Ekonomica Sharia: Jurnal Pemikiran dan Pengembangan Ekonomi Syariah Volume 6 Nomor 1 Edisi Agustus 2020 |95

dalam rangka meningkatkan likuiditas di pasar dan potensi pasar dalam menyerap sukuk.

2. Perlu ditingkatkan kerjasama dalam bentuk nota kesepahaman (MoU) dengan asosiasi-asosiasi pelaku pasar modal dan Bursa Efek Indonesia untuk memasukkan materi terkait pasar modal syariah ke dalam program pendidikan yang diadakan oleh asosiasi-asosiasi pelaku pasar modal dan Bursa Efek Indonesia. Hal tersebut dilakukan dalam rangka meningkatkan ketersediaan profesi dan lembaga penunjang pasar modal yang mengerti mengenai prinsip syariah.

3. Perlunya peningkatan peran aktif dan kerja sama antara Bapepam dan LK dengan Direktorat Jenderal Pajak dan pelaku pasar modal terkait pembahasan mengenai perlakuan perpajakan atas sukuk dalam rangka memperjelas ketentuan mengenai perlakuan perpajakan atas sukuk.

4. Perlu dilakukan sosialisasi kepada Emiten/PP yang belum pernah menerbitkan sukuk mengenai peraturan-peraturan terkait keterbukaan informasi dalam rangka meningkatkan pemahaman prinsip-prinsip syariah dalam penerbitan sukuk.

5. Perlu sosialisasi peran nyata keberadaan sukuk terhadap perkembangan pembangunan dalam bahasa yang lebih sederhana kepada masyarakat agar dapat menjadi alternatif investasi aman dan juga membantu pembanguan pemerintah dalam keterlibatan investasi dana secara syariah.

6. Adanya even-even edukasi masyarakat guna sosialisasi peran nyata investasi aman masyarakat melalui pilihan pada sukuk pemerintah. 
96 | Chandra Satria, Suandi, Faktor Minat dan Peran Sukuk Terhadap Pembangunan....

\section{DAFTAR PUSTAKA}

Angrum89, 2017 Jurnal AL-TIJARY, Vol. 02, No. 02,

Data SR 001 - SR 009, www.kemenkeu.go.id

Otoritas Jasa Keuangan. (2015). RoadMap Perbankan Syariah 2015-2019, Jakarta: Departemen Perbankan Syariah.

Peraturan Nomor IX.A.13 tahun 2009 tentang Penerbitan Efek Syariah.

Peraturan Pemerintah No, 45 Tahun 1995 tentang Penyelenggaraan Kegiatan Di Bidang Pasar Modal.

Putri, Rianda Ajeng Ardiyanti \&Herlambang, Leo. (2015). "Pengaruh Penerbitan Sukuk Ijarah terhadap ROA, ROE dan Earning Per Share Emiten di BEI Tahun 20092013”. Jurnal JESTT Vol. 2 No. 6.

Ryandini, Tya. (2014). "Pengaruh Dana Investasi Melalui Instrumen SUN dan SBSN Terhadap Pertumbuhan Ekonomi Indonesia”. Jurnal Al-Iqtishad, Vol. VI, No. 1.

Trisnawati, Desi. (2013). Sukuk Sebagai Alternatif Investasi Syariah di Indonesia. Jurusan Syariah Prodi Perbankan Syariah STAIN Salatiga.

Undang-Undang Republik Indonesia Nomor 19 tahun 2008 tentang Surat Berharga Syariah Negara.

Undang-Undang Republik Indonesia Nomor 40 tahun 2007 tentang Perseroan Terbatas.

Undang-Undang Republik Indonesia Nomor 8 tahun 1995 tentang Pasar Modal. 